
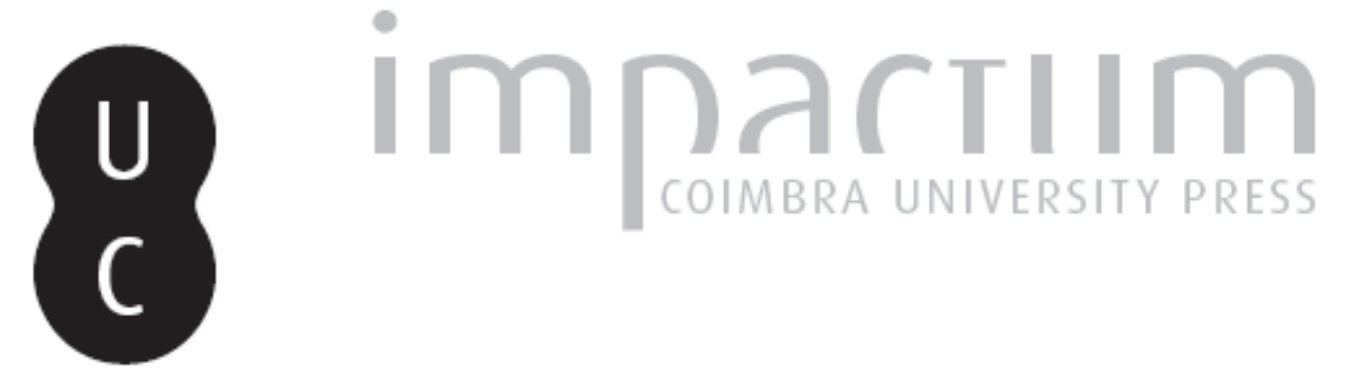

Grandes heroínas trágicas (2)

Autor(es): $\quad$ Silva, Maria de Fátima

Publicado por: Associação Portuguesa de Estudos Clássicos; Instituto de Estudos

Clássicos

URL

persistente:

URI:http://hdl.handle.net/10316.2/30376

DOI:

DOI:http://dx.doi.org/10.14195/0872-2110_52_2

Accessed : $\quad$ 26-Apr-2023 01:40:12

A navegação consulta e descarregamento dos títulos inseridos nas Bibliotecas Digitais UC Digitalis, UC Pombalina e UC Impactum, pressupõem a aceitação plena e sem reservas dos Termos e Condições de Uso destas Bibliotecas Digitais, disponíveis em https://digitalis.uc.pt/pt-pt/termos.

Conforme exposto nos referidos Termos e Condições de Uso, o descarregamento de títulos de acesso restrito requer uma licença válida de autorização devendo o utilizador aceder ao(s) documento(s) a partir de um endereço de IP da instituição detentora da supramencionada licença.

Ao utilizador é apenas permitido o descarregamento para uso pessoal, pelo que o emprego do(s) título(s) descarregado(s) para outro fim, designadamente comercial, carece de autorização do respetivo autor ou editor da obra.

Na medida em que todas as obras da UC Digitalis se encontram protegidas pelo Código do Direito de Autor e Direitos Conexos e demais legislação aplicável, toda a cópia, parcial ou total, deste documento, nos casos em que é legalmente admitida, deverá conter ou fazer-se acompanhar por este aviso. 


\section{Boletim de}

\section{Estudos Clássicos}

Associação Portuguesa de Estudos Clássicos Instituto de Estudos Clássicos

Coimbra

Dezembro de 2009 


\title{
GRANDES HEROÍNAS TRÁGICAS (2)
}

\author{
Hécuba, na Hécuba de Eurípides
}

A ficção dramática permite a Eurípides encarnar na sua protagonista, Hécuba, a velha rainha de Tróia, símbolo extremo da ruína humana, decepada de todos os bens que estruturam a civilização - 'sem filhos, sem marido, sem pátria’, 669 -, a mais completa degradação social, como uma espécie de cúmulo exemplar de decadência pessoal e cívica. Ao mesmo tempo que, sem respeito pela verosimilhança, a dotou de uma competência retórica, que a sua actuação ao longo de toda a peça nunca desmente. Pôde então envolvê-la em sucessivos conflitos retóricos com os mais temíveis adversários - com Ulisses, o exemplar completo do retórico contemporâneo; com Agamémnon, o comandante em chefe do inimigo; ou, finalmente, com a violência grotesca do bárbaro Polimestor.

Num contexto de dificuldades profundas, o acampamento aqueu na Trácia, que é uma espécie de microcosmos da realidade grega contemporânea, tornou-se um ponto de confluência de todas as sensibilidades sociais. Ulisses figura nele como protótipo do orador contemporâneo, sem escrúpulos, ousado, ambicioso. A sedução do seu discurso é claramente superficial; versátil, cativante, fluente, demagógico, é este o registo que sobressai numa primeira avaliação, onde a forma se impõe ao conteúdo. E a verdade é que, no primeiro confronto em que, na peça, Ulisses afirma a sua arete retórica, na assembleia dos Aqueus onde se discutia a satisfação da exigência de Aquiles de um geras para o seu túmulo, esses atributos lhe valem a vitória: 'persuade', ou seja, 'vence' (133).

Face à competência suprema do filho de Laertes, o coro de mulheres, que antevê o prolongamento iminente da discussão, agora no privado, perante Hécuba, a mãe que vai perder uma filha em nome da vénia devida a um herói já morto, encarna a população anónima, desarmada diante da habilidade retórica, frágil face ao poder esmagador de um universo que desconhece.

Hécuba, apesar de mulher, de troiana, de uma velha rainha vencida pelos acontecimentos, tem, na peça, uma verdadeira competência retórica. Anuncia-o desde logo a reacção que tem ao estímulo que lhe é dado pelo 
coro, para que se prepare para o agôn com Ulisses. Despojada de qualquer apoio, de pátria, de parentes e de amigos, Hécuba sente que é antes de mais de si mesma e dos argumentos que conseguir encontrar que depende o sucesso da sua causa: salvar a vida de Políxena. Sabe escolher os argumentos certos, ordená-los com lógica, esgrimi-los de acordo com a circunstância. É acutilante no enunciado, seleccionando as palavras certas e sublinhando, pela insistência oportuna em vocábulos chave, os conceitos que, a cada momento, traz a debate. Condimenta a racionalidade do discurso com o espectáculo emotivo do apelo e da súplica, sobretudo a rematar cada uma das suas intervenções, de modo a susceptibilizar o auditório difícil que sempre é o que lhe está destinado. Há, no entanto, uma aprendizagem que as circunstâncias lhe impõem ex abrupto. Não basta usar argumentos éticos e justos, não são esses os que obtêm sucesso num mundo feito de compromissos e de condicionalismos. Se necessário, é preciso avançar para razões amorais, apelar a motivos adika, não hesitar perante qualquer baixeza, legítima em nome do supremo objectivo da vitória. É esta a degradação retórica que acompanha todo o processo de decadência humana que a antiga senhora de Tróia sofre na peça.

Quando Ulisses chega, como mensageiro da decisão dos Aqueus (218228), omite a sua intervenção no processo e escuda-se no voto colectivo. É manifesto o seu desejo de executar rapidamente uma sentença, imoral e controversa, sem deixar margem a quaisquer outros argumentos. Hécuba, porém, não se deixa iludir pela frieza burocrática da comunicação. Sente, pelo contrário, que é chegada a hora de um agôn supremo, da troca decisiva de argumentos, para além dos inevitáveis soluços e lágrimas.

Com uma clara competência, o primeiro motivo que introduz é o de charis. O reconhecimento e a reciprocidade que exige de um favor prestado transita de um plano colectivo, o que relaciona o exército com o mais prestigiado dos seus elementos, para o privado, o que vincula Ulisses a uma Hécuba, outrora poderosa, a quem ficou a dever a própria vida, quando penetrou, como espião, em terreno inimigo e se viu identificado por Helena. A charis associam-se as ideias de xenia 'deveres de hospitalidade' e philia, 'a solidariedade', diversificando o conteúdo do conceito (251-257), a que se somam questões de 'justiça'. Do seu infortúnio, Hécuba parte, num encadeamento lógico, para a desventura que é, na existência humana, o contraponto coeso da felicidade e do poder.

Ulisses, instigado ao debate, não hesita na resposta que organiza, como expert que é em matéria retórica, numa perfeita simetria com o desafio que 
lhe foi lançado. Passando em claro o argumento da justiça, visivelmente desfavorável ao lado da condenação, expande-se sobre charis. Diz-se disposto a respeitar a reciprocidade que lhe é exigida, mas de um modo directo, circunscrito à sua benfeitora de outrora, Hécuba, e não à filha (301305). Mas além dessa charis pessoal, há uma outra charis, pública, que o enleia, a que deve, como membro de um colectivo, a um herói (304-305). E sem falar de justiça, Ulisses relativiza o valor da vida humana, sobrepondo ao carácter absoluto do princípio o condicionamento político do nomos (304308). Estão em jogo, lado a lado, os interesses de um homem, o primeiro dos heróis entre os seus pares, a par de uma jovem, mulher, anónima, estrangeira e cativa. Hécuba sai vencida deste recontro retórico, não porque lhe falte competência oratória, mas porque se limita a argumentos de justiça, a valores éticos, que não têm, perante a sociedade ambiciosa, amoral e pragmática que Ulisses representa, um peso decisivo.

Mas o que parecia o último dos golpes era apenas mais uma etapa num calvário de amarguras; pois já uma escrava, activa na preparação das exéquias de Políxena, era portadora de mais um golpe, a morte de Polidoro, desta vez vítima simplesmente da falsidade e da ambição do trácio Polimestor, a quem Príamo o confiara como a última esperança para a ressurreição futura de Tróia. Não se tratava agora da crueldade de um inimigo, mas do crime de traição cometido por um amigo e aliado, igualmente bárbaro; Polimestor, para mais, estava isento da pressão do seu povo, agia por iniciativa própria, e não em nome de quaisquer valores em conflito, mas da mais primária das ambições. Hécuba compreende que está diante de uma nova crise; mas muda de tom e passa a dar prioridade à vingança, a que tem de ajustar argumentos igualmente reprováveis.

Como se a nobreza de alma que ainda resiste a orientasse, são éticos os argumentos que ensaia junto de Agamémnon, o seu novo interlocutor, o chefe supremo dos Aqueus, de quem suplica justiça e a punição dos culpados. Vemo-la repetir a estratégia retórica antes usada com Ulisses: a súplica primeiro (787-788), e logo o seu principal argumento na circunstância, a falta de respeito pela piedade devida às leis divinas, além da quebra dos deveres impostos pela philia e xenia, por parte de Polimestor. Reclama uma reciprocidade infringida por quem outrora partilhou da sua hospitalidade em Tróia, do convívio à sua mesa, e da distinção de uma afinidade particular (793-796). E numa escala ascendente, após a impiedade e o assassínio, coloca o desrespeito pelos mortos, que o levou a deixar insepulto o cadáver da sua vítima. O apelo final de Hécuba perante Agamémnon retoma também os 
motivos anteriores, usados para com Ulisses: nomos, 'a lei', que é um valor divino, superior a todas as hierarquias humanas, inspirador de uma distinção essencial entre o que é justo e injusto.

Torna-se, mais uma vez, evidente que os princípios de que a rainha de Tróia se faz defensora perderam sentido nos representantes de um novo estado democrático. É a evidente indiferença de um Agamémnon que se afasta, incapaz de exercer as responsabilidades de chefe que lhe incumbem, que traz enfim ao de cima, na alma da rainha de Tróia, o seu lado mais tenebroso e, com ele, uma argumentação pragmática e amoral, mas que vence. Na sua nova abordagem da causa que defende, Hécuba mantém-se fiel aos valores em discussão, philia e charis; mas ao retomá-los, mostra como são relativos no seu mérito, como podem ser distorcidos e amesquinhados, por interesses pequenos e condenáveis. Philia é, neste caso, o vínculo erótico que Agamémnon mantém com Cassandra, as noites partilhadas, os abraços de amor (828-829); charis o reconhecimento devido a uma amante, a quem se deve o prazer de noites memoráveis $(830,832)$. Não restam dúvidas sobre a escala de valores com que Hécuba apela, nem da sua hierarquização em sociedade. Porque finalmente eis que a primeira vitória lhe sorri, na cedência de Agamémnon a arbitrar o último dos agones a que o poeta a sujeita, contra Polimestor.

Desta vez Hécuba intervém em segundo lugar, apenas para responder e desmontar os argumentos do adversário. É simples a sua intervenção, quando se trata apenas de legitimar um castigo violento que já foi aplicado antes da sentença pela sua raiva contra o assassínio do mais novo dos seus filhos. De resto, tudo parece tão nítido de razões que a condenação é segura (12341235). Em discussão persiste um valor que cruza toda a peça, a philia, que é, no limite, invocado como justificação para um assassinato. Polimestor não pode, por qualquer habilidade retórica, negar o homicídio de que é acusado, uma evidência. Por isso adopta a táctica ajustada à situação: confessa o crime (1132-1136), como ponto de partida para o argumento da legitimidade: o bom senso e uma louvável prudência, que o levou a aniquilar um possível renascimento de Tróia por iniciativa do mais novo dos herdeiros de Príamo.

Depois de um preâmbulo doutrinário sobre a justeza dos argumentos face aos actos cometidos, dirigido ao juiz como captatio beneuolentiae, Hécuba desmonta, com cuidadosa simetria, cada argumento do adversário (1187-1196). A philia invocada por Polimestor, como uma aliança entre Gregos e Bárbaros, parece, à luz da evidência, pura falácia (1197-1201). Será contra natura o uso da philia numa relação, humana e política, inviável. 
Despida de uma capa de dignidade, a verdade crua, despojada de argumentos, chama-se 'ouro', a ambição primária que justificou o mais vil dos actos (1206-1207). Mas por trás desse móbil prioritário está o jogo político; Polimestor não agiu quando Tróia era poderosa, só a ruína da corte de Príamo o incentivou ao crime. Poderá chamar-se esta atitude calculada philia (12081216)? Ou que philia poderia recomendar que Polimestor guardasse para si o ouro, em vez de o pôr à disposição dos aliados fustigados pela dureza de um longo combate (1217-1223)? Teria então, em momento de crise, sido oportuno que desse mostras de uma verdadeira filia, para com aqueles que eram os seus verdadeiros aliados, os senhores de Tróia (1228-1232). E Hécuba termina com uma definição do que seja a verdadeira philia, como que impulsionada, no meio de uma controvérsia de valores, a recordar o seu mérito essencial (1226-1227): 'É na desgraça que se reconhece a amizade verdadeira, porque à ventura, enquanto dura, não faltam os amigos’.

M. F. S. S. 